MONIKA GOLONKA

Warszawa, Polska - Warsaw, Poland

\title{
Edukacja przedsiębiorczości: perspektywa realistyczna
}

\section{Entrepreneurship Education - a Realistic Perspective}

Streszczenie: W artykule podjęta została tematyka efektów edukacji przedsiębiorczej w rzeczywistości społeczno-gospodarczej. Analizie poddany został także cel edukacji przedsiębiorczej, określony przez Komisję Europejską, a następnie przekazywane treści i sposoby kształcenia, a dalej założenia teoretyczne leżące u podstaw przyjętych koncepcji, zwłaszcza wizji natury człowieka. Praca ma charakter poznawczy - teoretyczny - a zastosowana metoda to analiza adekwatnej literatury, rezultatów badań, oficjalnych dokumentów i raportów, podręczników oraz materiałów edukacyjnych. W rezultacie przeprowadzonych analiz zdiagnozowane zostały główne obserwowane w rzeczywistości problemy oraz wskazane ich przyczyny. W odpowiedzi na nie zaproponowano uwzględnienie dorobku realistycznej tradycji intelektualnej. Z tej perspektywy najistotniejszą rolę w poznawaniu i uczeniu się odgrywają wola i rozum ucznia, dzięki którym kieruje się on do swojego celu. W artykule omówione zostały także: rola nauczyciela w edukacji, możliwości skutecznego nauczania oraz pojęcie dobra wspólnego w działalności edukacyjnej i przedsiębiorczej.

\begin{abstract}
This paper examines the effects of entrepreneurial education in the socio-economic reality, and presents the results of analysis of the aim defined by the European Commission, the content and methods of teaching entrepreneurship, as well as theoretical assumptions underlying the developed concepts, especially regarding the human nature. The paper is of a theoretical character. Adequate literature, research results, official documents and reports, textbooks and educational materials have been analysed for the purpose of this work. As a result of research, the major problems - as well as their reasons - have been identified. Finally, realistic intellectual tradition has been proposed as a remedy for these problems. Realistic philosophy indicates the supreme role of will and intellect of a student in his cognition, as well as in his learning. These mental powers direct him to his aim. Also, the realistic role of teacher has been explained, as well as the concept of common good in education and entrepreneurship.
\end{abstract}

Słowa kluczowe: edukacja przedsiębiorcza; efekty edukacji; nauczanie; nauki pedagogiczne; nauki społeczne; perspektywa realistyczna; rola nauczyciela; rozwój intelektualny; rozwój społeczno-gospodarczy

Keywords: economic and social development; entrepreneurial education; impact of education; intellectual growth; pedagogical sciences; social sciences; teaching; role of a teacher 
Otrzymano: 9 lipca 2019

Received: 9 July 2019

Zaakceptowano: 30 września 2019

Accepted: 30 September 2019

\section{Sugerowana cytacja/Suggested citation:}

Golonka, M. (2019). Edukacja przedsiębiorczości: perspektywa realistyczna. Przedsiębiorczość Edukacja [Entrepreneurship - Education], 15(2), 40-58. doi: 10.24917/20833296.152.3

Wstęp

W literaturze polskiej i zagranicznej podkreślana jest zasadnicza rola edukacji w zakresie przedsiębiorczości, nazywanej także edukacją przedsiębiorczą, dla rozwoju społeczno-gospodarczego. Rozliczne działania edukacyjne, propagandowe, programy wsparcia opracowywane i finansowane z funduszy Unii Europejskiej mają za zadanie kształtować przedsiębiorcze postawy młodych ludzi z krajów europejskich i pomóc im w tworzeniu nowych przedsiębiorstw, oferujących nowe miejsca pracy.

W wyniku tych działań znacząco rozrosła się oferta edukacyjna w obszarze przedsiębiorczości, dzięki czemu stanowi ona obecnie jeden z najszybciej rozwijających się sektorów edukacji w skali międzynarodowej (np. Sirelkhatim, Gangi, 2015). Wzrosła także znacząco liczba uczniów i studentów, którzy z takiej edukacji, oraz wspierających ją programów, korzystają (Rideout, Gray, 2013). Niewiele wiadomo natomiast o tym, czy i w jaki sposób przekłada się to na rzeczywistość społeczno-gospodarczą. Niniejsza praca ma za zadanie wypełnić tę lukę, uwzględniając także szerszy kontekst edukacji biznesowej i menedżerskiej.

Metodą temu służącą jest analiza adekwatnej literatury ${ }^{1}$, oficjalnych dokumentów, podręczników i materiałów z zakresu przedsiębiorczości, a także sposobów kształcenia przyszłych przedsiębiorców, założeń teoretycznych, przyjętych za podstawę ich opracowywania i realizacji w nauczaniu.

W pracy zaprezentowany został cel, który Komisja Europejska postawiła przed krajami członkowskimi UE, w tym Polską, a także środki do niego prowadzące, a następnie przedstawione zostały wyniki analizy efektów realizacji tego celu w rzeczywistości społeczno-gospodarczej.

Następnie podsumowane zostały rezultaty poszukiwania źródeł obserwowanych problemów na podstawie analizy treści i sposobu kształcenia w edukacji przedsiębiorczej. Uwzględniona tu została leżąca u ich podstaw teoretyczna wizja człowieka, przyjęta w naukach pedagogicznych i społecznych, w tym także z zakresu przedsiębiorczości. W dalszej części pracy zaproponowane zostało rozwiązanie polegające na weryfikacji tej wizji i uwzględnieniu realistycznej perspektywy filozoficznej. W jej świetle omówione zostały kolejno: znaczenie celu i porządku działań człowieka oraz jego możliwości poznawania i uczenia się.

W końcowej części pracy poruszona została kwestia dobra wspólnego, bez którego rzeczywisty rozwój społeczno-gospodarczy nie jest możliwy, a także wyjaśniona została rola nauczyciela i możliwości skutecznego nauczania potencjalnych przedsiębiorców we współczesnych instytucjach edukacyjnych oraz w szkołach wyższych.

${ }^{1}$ Artykuły na temat edukacji przedsiębiorczej opublikowane w czasopismach znajdujących się w bazach EBSCO, Elsevier (ScienceDirect), Emerald, SAGE, Taylor\&Francis, Springer, Wiley-Blackwell, wyszukiwane były wg słów kluczowych, przede wszystkim: „entrepreneurship education”, „entrepreneurial education”. 
Cel edukacji przedsiębiorczej i dobrane środki

Przedsiębiorczość, tworzenie nowych przedsiębiorstw, a dokładnie - zwiększenie liczby przedsiębiorców, zdaniem urzędników UE, ma zapewnić Europie rozwój i tworzenie nowych miejsc pracy. Jest to więc cel, który stawia Komisja Europejska² przed każdym z krajów członkowskich, wskazując przy tym edukację przedsiębiorczą jako pierwszy, najważniejszy środek mający służyć jego osiągnięciu.

W opinii urzędników UE, dzięki takiej edukacji powinno się rozwijać przedsiębiorcze nastawienie (mind set) (KE, 2019) ${ }^{3}$ oraz mają się kształtować przedsiębiorcze postawy (attitudes), (Holmgren, From, 2005; KE, 2019).

Jak wynika z dokumentów KE, przedsiębiorczość jest też rozumiana jako umiejętność lub kompetencja. Rozwój jej jest możliwy, jak wyjaśniono w dokumentach, przez trening praktyczny, rzeczywiste doświadczenie i pracę projektową, a także przez nauczanie przedsiębiorczości w ramach odrębnego przedmiotu lub w powiązaniu $\mathrm{z}$ innymi przedmiotami (KE, 2019).

W praktyce, w instytucjach edukacyjnych w krajach UE przedsiębiorczość najczęściej jest nauczana jako osobny przedmiot. Tworzone są także kierunki studiów i specjalności dedykowane nauce przedsiębiorczości.

Środki wymienione przez KE wyrażone są w programach nauczania jako predefiniowany zakres wiedzy, którą należy dostarczyć uczniom czy studentom, oraz wytyczne dotyczące sposobu nauczania, obejmujące zwłaszcza zespołową pracę projektową.

$\mathrm{Z}$ informacji dotyczącej podstawy programowej ${ }^{4}$ dla szkół ponadgimnazjalnych w zakresie edukacji przedsiębiorczej można wnioskować, że chodzi o wiedzę z zakresu: „Nauk ścisłych, przyrodniczych i humanistycznych, ale także społecznych, a zwłaszcza ekonomicznych”, gdyż „Wiedza ta daje podstawy do kształtowania umiejętności oraz postaw przedsiębiorczych” (KE, 2019). „Postawy przedsiębiorcze i wspierające je umiejętności powinny zatem pośrednio z tej wiedzy wynikać” (KE, 2019).

W adekwatnej literaturze można znaleźć wskazówki dotyczące środków pomocniczych, mających służyć celowi postawionemu przez KE; są to przede wszystkim: rozbudzanie innowacyjności i kreatywności (por. Bernard, Herbst, 2018; Sanchez-Garcia i in., 2019), oddziaływanie na emocje (Grichnik i in., 2010; Jogdand, Sharma, 2019; Sanchez-Garcia i in., 2019; Zampetakis i in., 2016), pasję (Cardon i in., 2009), a także zachęcanie i wpływanie na intencje i motywację (Barosso-Tanoira i in., 2017; Ferreira i in., 2012; Sanchez, 2011).

\section{Efekty edukacji przedsiębiorczej w rzeczywistości społeczno-gospodarczej}

Jeśli chodzi o weryfikację rzeczywistych efektów podejmowanych działań edukacyjnych, trudno doszukać się rezultatów analiz czy badań temu poświęconych. Wprawdzie w dostępnych publikacjach odnaleźć można rezultaty badań nad rozmaitymi czynnikami związanymi z edukacją przedsiębiorczą (np. EC, 2012, 2016) i ich wzajemnymi korelacjami, lecz brakuje rzetelnych raportów dotyczących rzeczywistych efektów działań edukacyjnych, zwłaszcza w odniesieniu do stawianego przez KE celu.

\footnotetext{
${ }^{2}$ „To bring Europe back to growth and create new jobs, we need more entrepreneurs”. KE (2019).

${ }^{3}$ https://ec.europa.eu/growth/smes/promoting-entrepreneurship/support/education_en

${ }^{4}$ Programy nauczania wg rozporządzeń Ministerstwa Edukacji Narodowej. Pozyskane z: podstawaprogramowa.pl (dostęp: 2019, 12 maja).
} 
Trudno też znaleźć oficjalne raporty czy analizy KE prezentujące dane na temat przełożenia się edukacji przedsiębiorczej - oraz licznych programów ją wspierających, często finansowanych $\mathrm{z}$ funduszy unijnych - na rzeczywiste działania przedsiębiorcze (np. EU, 2006 - przykład Holandii). A spośród rezultatów badań akademickich, które dotąd zostały zrealizowane w tym obszarze, większość nie spełnia kryteriów rzetelnych metodologicznych analiz (Rideout, Gray, 2013).

Większość zrealizowanych badań dotyczy związku pomiędzy korzystaniem z edukacji przedsiębiorczej a zainteresowaniem przedsiębiorczością czy też deklarowaną intencją prowadzenia własnej działalności u uczniów i studentów, gdyż liczni badacze przyjęli założenie na temat powiązania intencji z rzeczywistymi działaniami (za: Bird, 1992). Badania te nie dostarczają jednak jednoznacznych wniosków. Przykładowo niektóre studia wskazują na pozytywną, inne zaś na negatywną korelację (zob. Albornoz, Martinez, 2016; Dogan, 2015; Fayolle, Gailly, 2013; Sirelkhatim, Gangi, 2015).

Samo zainteresowanie przedsiębiorczością czy też deklarowane intencje przedsiębiorcze niekoniecznie zresztą przekładają się na podejmowanie rzeczywistych działań. Między innymi E. Rideout i D. Gray (2013) analizowali liczbę osób zainteresowanych działalnością przedsiębiorczą w USA. Okazało się, że w wyniku edukacji zainteresowanie własną działalnością znacząco wzrosło (w latach 1997-2011 o 77\%). Jednak okazało się także, że edukacja ta nie przekłada się na rzeczywistą działalność gospodarczą, tj. powstawanie większej liczby przedsiębiorstw. Od dziesięcioleci utrzymuje się stała liczba osób angażujących się w działania przedsiębiorcze (np. w USA na poziomie 10-12\%).

W Europie rzecz ma się podobnie. Wprawdzie uczniowie i studenci wykazują zainteresowanie przedsiębiorczością (podkreślane w dokumentach KE - intencje, przedsiębiorcze nastawienie - np. EU 2020 Strategy), lecz nie przekłada się to na działania w rzeczywistości społeczno-gospodarczej (np. Cardoso, 2018). Wprawdzie z dokumentów PARP (2017) wynika, że rośnie liczba przedsiębiorstw (ok. 7\%), jednak z danych sprzed 2006 r. wynika, że wcześniej wzrost ten był większy (10\%) (Krawczyk, 2006; PARP, 2006). Okazuje się też, że w Polsce liczba małych firm w rzeczywistości nawet się zmniejszyła (2017, 2018 r.), o 4,1\% (GUS, 2017).

$\mathrm{Z}$ dostępnych analiz prowadzonych przez urzędników UE, których rezultaty zostały zaprezentowane $\mathrm{w}$ dokumentach KE, wynika natomiast, że absolwenci przedsiębiorczości są częściej zatrudniani niż absolwenci innych kierunków (KE, 2019). Wskazuje to na efekt odwrotny od zamierzonego, gdyż edukacja przedsiębiorcza miała służyć zwiększeniu liczby przedsiębiorstw i tworzeniu nowych miejsc pracy, a nie wypełnieniu ich w już funkcjonujących przedsiębiorstwach czy instytucjach.

W rzeczywistości okazuje się też, że niewiele pomagają wsparcie instytucjonalne, finansowe oraz liczne fundusze, dofinansowanie, rozliczne programy, stypendia, publikacje, działania propagandowe. Nawet w jednym z najbogatszych państw świata - Norwegii - pomimo wyjątkowo wysokich środków finansowych przeznaczanych na edukację przedsiębiorczą i tworzenia zaawansowanych rozwiązań instytucjonalnych i programów wspierających, nie przekłada się to na rzeczywistość społeczno-gospodarczą (Stroen, 2014). Udział absolwentów edukacji przedsiębiorczej wśród wszystkich osób samozatrudnionych jest bardzo niski.

Natomiast jak wynika z dostępnych danych, z pewnością w większości krajów świata znacząco rozrosła się oferta edukacyjna z zakresu przedsiębiorczości (np. w USA prowadzi ją ponad $90 \%$ akredytowanych szkół) oraz zwiększyła się liczba uczniów i studentów 
biorących w nich udział (Rideout, Gray, 2013). Edukacja przedsiębiorcza jest jednym z najszybciej rosnących obszarów w edukacji w skali międzynarodowej (Sirelkhatim, Gangi, 2015).

Z dostępnych publikacji naukowych można wnioskować, że na pytanie o to, jak ta edukacja przedsiębiorcza funkcjonuje - jak podsumowali DeTienne i Chandler (2004) - środowisko akademickie ma następującą odpowiedź: „Tak naprawdę nie wiadomo”. Podobną odpowiedź można uzyskać na pytanie o to, czy w ogóle ta edukacja „jakoś” funkcjonuje (DeTienne, Chandler, 2004).

Jednak edukacji przedsiębiorczej nie sposób rozpatrywać w oderwaniu od szerszego kontekstu, zwłaszcza od edukacji biznesowej i menedżerskiej; nauk pedagogicznych i społecznych, a zwłaszcza nauk o organizacji i zarządzaniu, skąd wywodzi się przekazywana uczniom i studentom wiedza na temat przedsiębiorczości. Tutaj z kolei autorzy licznych publikacji akademickich zwracają uwagę na fakt, że efekty edukacji biznesowej i menedżerskiej przynoszą niekoniecznie pozytywne rezultaty w rzeczywistości społeczno-gospodarczej.

Przykładowo W. Bennis i J. O’Tolle (2005) zwracają uwagę na to, że u podstaw wydarzeń mających negatywny wpływ na sytuację społeczno-gospodarczą, takich jak kryzysy finansowe oraz skandale gospodarcze, stały decyzje konkretnych osób, wykształconych w wiodących szkołach biznesu i zarządzania. Niektórzy teoretycy organizacji i zarządzania uważają, że „dobra praktyka wynika często ze stosowania teorii” (Latusek i in., 2018: 14). Jednak S. Ghoshal (2005) zauważa też, że - konsekwentnie - złe teorie psują dobrą praktykę. Często także tworzone na uniwersytetach koncepcje, modele i narzędzia służą praktykom - zwłaszcza menedżerom - jako naukowe uprawomocnienie niekorzystnych dla innych decyzji, stanowiąc także niejako usprawiedliwienie porzucenia odpowiedzialności moralnej (Ghoshal, 2005, por. Golonka, 2018).

W efekcie dochodzi do obserwowanych w rzeczywistości społeczno-gospodarczej coraz liczniejszych nadużyć względem pracowników, klientów, a nawet społeczeństwa, traktowania ich w sposób instrumentalny, często pod pozorem podejmowania działań na ich korzyść ${ }^{5}$ (zob. np. Craze, 2018).

W literaturze toczy się także dyskusja na temat kryzysu szkół biznesu i zarządzania (Bachrach i in., 2017; Bennis, O’Tolle, 2005; Golonka, 2018; Hoffman, Maynard, 2015; Pfeffer, Fong, 2002), a także kryzysu w nauce, zwłaszcza jakości badań naukowych (m.in. Aguinis i in., 2017; Begley 2013, Saltelli, Funtowicz, 2017) czy kryzysu autorytetu naukowego (Benessia i in., 2016; Saltelli, 2016).

W związku z powyższym można mieć uzasadnione wątpliwości co do skuteczności realizacji celu postawionego przez KE, jak też możliwości jego realizacji w przyszłości, biorąc pod uwagę dotychczasowe rezultaty, a także szerszy, społeczno-gospodarczy oraz naukowy i edukacyjny kontekst oraz doświadczenia innych krajów - nawet tych uznawanych za najbardziej rozwinięte gospodarczo.

\footnotetext{
${ }^{5}$ Przyczynili się do tego pracownicy uniwersytetów i tworzone przez nich od lat 70. ubiegłego wieku teorie, promujące relatywizm w organizacjach, w tym przedsiębiorstwach; stąd rozmycie celów i interesów poszczególnych uczestników organizacji, metod i wykorzystywanych środków służących ich osiągnięciu (zob. Golonka, 2019: 105 za: Lombard, 1971). Liczne wynikające $z$ tego koncepcje, metody czy narzędzia z założenia oparte na „dobrowolnym przymusie” i wiążące się z instrumentalnym traktowaniem człowieka, a nawet całego społeczeństwa (zob. Life and Work Balance, CSR itp.), nie przynoszą rzeczywistych korzyści nikomu, nawet wykorzystującym je menedżerom (np. Craze, 2018).
} 
Zastrzeżenia budzić może także sam stawiany przez urzędników KE cel, czyli większa liczba przedsiębiorców, gdyż większa ich liczba niekoniecznie przełożyć się może na realny rozwój społeczno-gospodarczy krajów Europy. Dodatkowo, brakuje określenia, co konkretnie ten rozwój w opinii komisarzy UE oznacza. Nie ma także zupełnie mowy o dobru, które jest przecież naturalnym celem człowieka - i społeczeństwa mającego przede wszystkim umożliwiać rozwój osobie ludzkiej (np. O’Brien, 2009; Sison, Fontrodona, 2013; Sinson i in., 2012; Woźniak, 2018). Nie ma zresztą także żadnej dyskusji na temat samego celu.

W dalszej części pracy zaprezentowane zostały rezultaty analizy przekazywanej wiedzy, czyli treści kształcenia w edukacji przedsiębiorczej oraz sposobu kształcenia. Na podstawie rezultatów analizy zidentyfikowane i wyjaśnione zostały główne przyczyny zaistniałych problemów oraz wskazania dotyczące możliwości ich rozwiązania.

\section{Treści kształcenia}

Głównym celem prowadzenia działalności gospodarczej, wskazywanym w licznych publikacjach w Polsce, w tym w podręcznikach z zakresu przedsiębiorczości - zarówno dla uczniów szkół średnich, jak i dla studentów szkół wyższych - jest osiągnięcie zysku ekonomicznego (m.in. Bućko i in., 2005; Lichtarski, 2005; Pietraszewski, Strzelecka, 2012; Sudoł, 2006; Wawrzyniak, 1998 za: Belidon, Say, Mendel, 2012). Niekiedy jako cel wskazywana jest także efektywność (np. Żurek, 2007) albo osiągnięcie konkretnych korzyści (np. Buczyńska, 2007) czy zaspokajanie własnych potrzeb (np. Hawaj, 2015; Kożuch, Dyhdalewicz, 2004; Kużdżał, 2015).

Takie założenie dotyczące celu przedsiębiorczości wywodzi się z prac takich teoretyków, jak M. Friedman (1970) czy M. Jensen i W. Meckling (1976). Jednak nawet wstępna analiza publikacji podejmujących tę tematykę wskazuje na to, że - jak podsumowali m.in. A.J. Sison i J.I. Fontrodona $(2006,2012)$ - takie założenia dotyczące celu prowadzenia działalności gospodarczej były także wielokrotnie kwestionowane przez innych teoretyków, m.in. P. Druckera (1955), E.F. Fama, (1980), R.E. Duska (1997), A.V. Abela (2001), C. Handy'ego (2002), R.E. Freemana, A.C. Wicksa, B. Parmara, (2004), S. Ghoshala (2005), A.J. Sisona, (2007), A.J. Sisona, J.I. Fontrodona (2011), A.J. Sisona, I. Ferrero (2015) czy M. Huhna (2018).

Wprawdzie w podręcznikach mowa o celach dodatkowych, tj. społecznych (najczęściej ze wskazaniem dla organizacji non profit), jednak prezentowane są one zasadniczo w kontekście uzyskiwania różnego rodzaju korzyści osobistych. Dodatkowo, jak zauważył m.in. Lombard (1971), takie szersze zdefiniowanie celów od czasu „wdrożenia” relatywizmu do organizacji, służy najczęściej wskazaniu możliwości i narzędzi do realizacji tego samego celu - zysku ekonomicznego lub inaczej rozumianych korzyści osobistych - tyle, że w bardziej zawoalowany sposób.

Wynika z tego, że w środowisku akademickim nie ma jednomyślności co do celu prowadzenia działalności gospodarczej. Stąd też prezentowanie w treściach kształcenia wiedzy nieuzgodnionej przez samych jej twórców jest niespójnością wprowadzającą w błąd uczniów i studentów, a także nauczycieli. 
Jak wynika z dostępnych podręczników i materiałów edukacyjnych ${ }^{6}$, wychodząc od tak zdefiniowanych celów, uczniowie zaznajomić się następnie mają ze sposobami ich osiągnięcia. Na dostarczaną wiedzę składają się zagadnienia dotyczące instytucji, rynku, kapitału, giełdy papierów wartościowych, transformacji ustrojowej, inwestowania, technik i metod marketingowych, planowania (w tym przygotowywania biznesplanu), finansów, wykorzystania narzędzi i dostępnych technologii, efektywności itd. W efekcie uczeń ma się dowiedzieć, w jaki sposób napisać biznesplan, pozyskać inwestora, wziąć kredyt, negocjować, wpłynąć na klientów, aby kupili oferowane produkty czy usługi itd. Jeśli chodzi o wiedzę na temat własnej osoby jako potencjalnego przedsiębiorcy, uczeń ma opanować materiał dotyczący tego, jakie kompetencje powinien mieć przedsiębiorca, jak powinien się zachowywać i wyglądać, a nawet - jaką mieć mimikę (np. Puchalska, Kasprzyk, Pusz, 2018) - a także w jaki sposób może zdobywać potrzebne niezliczone kompetencje i umiejętności.

Także i w tym przypadku liczne publikacje, w których podejmowana jest krytyka tego rodzaju treści nauczania, zwłaszcza w kontekście jej realnych efektów dla menedżerów, pracowników, jak i całego społeczeństwa (zob. np. Holmgren, From, 2005; Pitt-Watson, Quigley, 2019) nie są uwzględniane.

Przedsiębiorczość w ten sposób pojmowana, mająca na celu zaspokojenie własnych potrzeb, uzyskanie zysku ekonomicznego czy zwiększenie efektywności albo osiągnięcie osobistej satysfakcji przez służące temu coraz efektywniejsze wykorzystywanie zasobów wewnętrznych i zewnętrznych (włączając w to innych ludzi), za pomocą licznych „naukowych" metod, technik i narzędzi, może raczej zniechęcać. I rzeczywiście, wstępnie zainteresowani uczniowie szybko tracą zapał (zob. np. Cardoso i in., 2018; DeTienne, Chandler, 2004; Moreau, Raveleau, 2006).

Niektóre badania pokazują nawet negatywną korelację pomiędzy edukacją przedsiębiorczą a chęcią podjęcia działań przedsiębiorczych przez uczniów, którzy przed podjęciem takiej edukacji mieli własne doświadczenia przedsiębiorcze (np. Fayolle, Gailly, 2013) lub też pochodzą z rodzin przedsiębiorców.

\section{Sposób kształcenia}

Nauczanie przedsiębiorczości w praktyce sprowadza się do następujących działań: ustalanie treści kształcenia, wyznaczanie celów kształcenia, dostarczanie wiedzy i próby oddziaływania na chęci czy intencje uczniów czy studentów - przez pobudzanie, zachęcanie, wpływanie na motywację (KE, 2008-2020).

Jeśli wziąć pod uwagę fakt, że mowa o „oddziaływaniu na intencje”, czy „motywowaniu” potencjalnych przedsiębiorców, taki sposób nauczania może budzić zastrzeżenia. Zwłaszcza jeśli zwróci się uwagę na to, iż u podstaw takiego sposobu nauczania leży założenie o konieczności zewnętrznego przymusu, podczas gdy samą istotą przedsiębiorczości, jak wynika z praktyki, jest dążenie przedsiębiorców do niezależności i autonomii (Gibcus, 2004, Hornaday, Aboud, 1971; Sexton, Bowman, 1985), improwizacji w odpowiadaniu rzeczywistości (Baker i in., 2003; Chia, Holt, 2009; Chia, MacKay, 2007; Hmieleski, Corbett, 2003), a ponadto innowacyjności (Huhn, 2018 za: Adam Smith, 1776, 1790).

\footnotetext{
${ }^{6}$ Na przykład: Niesłuchowski, 2017, seria Krok w przedsiębiorczość (Makieła i Rachwał, 2015, Podręcznik do przedsiębiorczości dla szkół ponadgimnazjalnych), EduGate, 2014, podstawaprogramowa.pl, program Jestem Przedsiębiorczy, Rachwal, 2012) i in.
} 
Wspomnianą konieczność zewnętrznego przymusu zakłada już sama koncepcja motywacji i motywowania. Została ona opracowana w XX w. w środowisku akademickim, dla uzasadnienia możliwości oddziaływania na zachowanie i potrzeby ludzi, adekwatnie do toczącego się wówczas dyskursu na temat społecznej kontroli (Danziger, 1997). Założenia teoretyczne przyjęte do opracowania tej koncepcji opierają się na przekonaniu, że życie wewnętrzne człowieka, a dokładnie - władze intelektualno-wolitywne, mogą stanowić przedmiot zewnętrznej kontroli (Danziger, 1997). Stąd także wywodzi się postrzeganie i traktowanie człowieka jako przedmiot oddziaływania (Golonka, 2018, 2020, w publikacji) i kontroli (Golonka, 2018, 2020, w publikacji) w systemie edukacji, a także w licznych współczesnych organizacjach.

Błędy i nieścisłości tej koncepcji oraz tworzonych na jej podstawie teorii i metod były wielokrotnie wykazywane w literaturze (np. Alderfer, 1969; Berkowitz, 1969; Danziger, 1997; Hunt, Hill, 1969; Woźniak, 2018a), jednak pomimo tego opartych jest na niej wiele współcześnie tworzonych teorii, modeli i metod w naukach pedagogicznych i społecznych, w tym także o organizacji i zarządzaniu, a dalej - w edukacji przedsiębiorczej.

Co więcej, pojęcie motywowania, jak i opracowywane metody i narzędzia służące motywowaniu, od początku ściśle związane były z próbami wpływania na potrzeby i decyzje zakupowe konsumentów, a wykorzystywane przez sprzedawców i twórców reklam (Danziger, 1997: 113, por. Perrin, 1023; Troland, 1928; Young, 1936). Zatem sposób nauczania, w tym w edukacji przedsiębiorczej, opiera się na tych samych założeniach, jakie leżą $\mathrm{u}$ podstaw koncepcji, metod i narzędzi wykorzystywanych w działaniach reklamowych i sprzedażowych; mających na celu wpływanie na chęci czy wytworzenie nowych - niekoniecznie realnych - potrzeb (Dezinger, 1997 za: Overstreet, 1925; Strong, 1925).

Takie „motywowanie” odbywać się ma przez oddziaływanie na sferę zmysłową człowieka (Woźniak, 2018a). Poddawani takim działaniom uczniowie i studenci (a także nauczyciele $^{7}$ ) uczą się, w jaki sposób podobne działania wykorzystywać z kolei względem innych ludzi - klientów, pracowników, partnerów biznesowych, społeczeństwa - w celu zaspokojenia własnych (także niekoniecznie realnych) potrzeb.

Nacisk na pracę zespołową, która ma w opinii urzędników UE służyć kształtowaniu kompetencji społecznych, w praktyce nauczania nakłada obowiązek projektowego, kolektywnego realizowania prac zaliczeniowych przez uczniów czy studentów. Twórcy standardów kształcenia przyjęli wizję wywodzącą się z tych samych źródeł, co koncepcja motywowania, czyli XX-wiecznego dyskursu na temat kontroli społecznej. U podstaw tej wizji leży wyobrażenie na temat społeczeństwa jako agregatu indywidualności (Dezinger, 1997), na który można wpływać przez wskazywanie predefiniowanych celów jako prowadzących do dobra i przekonywanie owych indywidualności o konieczności ich realizacji (zob. Golonka, 2020, w publikacji, za: Mayo, 1933; Robbins, 1943; Zaleznik i in., 1958; Whyte, 1956).

\section{Człowiek zmysłowy}

Analizując przyczyny opisywanych problemów, a nawet absurdów w edukacji - w tym przedsiębiorczej, jak też przyczyny braku przełożenia wysiłków nauczycieli na rozwój uczniów, a dalej na rzeczywistość społeczno-gospodarczą, można dotrzeć do samych ich źródeł, czyli teoretycznych założeń na temat człowieka i jego natury, które przyjęli twórcy

${ }^{7} \mathrm{~W}$ literaturze jest np. mowa o konieczności wsparcia i zachęt dla nauczycieli przedsiębiorczości, w postaci dostępu do nowych technologii, nowoczesnych metod nauczania itp. (Rachwał, 2012: 12). 
opisywanych koncepcji. Poznanie tych założeń jest niezbędne dla zrozumienia przyczyn obecnej sytuacji i znalezienia konstruktywnych rozwiązań. Niektórzy badacze zauważyli już konieczność analizy i weryfikacji historycznych i filozoficznych korzeni obserwowanych problemów (np. Saltelli, Funtowicz, 2017).

Okazuje się, że twórcy dominujących obecnie koncepcji w naukach pedagogicznych i społecznych przyjęli wizję człowieka i jego natury opracowaną przez filozofów nowożytnych, pomijających odkrycia filozofów klasycznych. Zgodnie z tą wizją ${ }^{8}$, człowiek ma naturę zmysłową - sensualistyczną - co oznacza, że zmysły i emocje człowieka należą do sfery motywacji i dążeń, a rozum ma wykonywać jedynie działania operacyjne (zob. Woźniak, 2019). Zatem konsekwentnie, motywacja człowieka, jak też i podejmowane w oparciu o nią działania, wywodzą się z jego zmysłów i emocji.

Przyjęcie takiej wizji natury ludzkiej prowadzi do uznania za motor podejmowania przez człowieka działań, w tym przedsiębiorczych, chęć zaspokajania własnych potrzeb. W edukacji przedsiębiorczej przejawia się to m.in. w treściach podręczników i materiałów edukacyjnych w stwierdzeniach takich jak: „Motywem działania są potrzeby, a dokładnie nieograniczone potrzeby” (Kużdżał, 2019, Kużdżał, 2019: 29), czy też „Wiele potrzeb wynikających z fizjologii, psychiki i warunków życia” (Hawaj, 2019: 5).

Sensualistyczna koncepcja człowieka wyraża się też w uznawaniu nadrzędnego znaczenia uczuć, emocji, pasji w przedsiębiorczości - oraz w działaniach edukacyjnych (Borowiec i in., 2014; Cardon i in., 2009; Werner-Waliszewska, Zawadzka, 2015'), a nawet zmysłowych, powierzchownych wrażeń - np. ubiór, gesty, mimika itp. (Hawaj, 2019).

Sięgając do źródeł innego pojęcia, wykorzystywanego w edukacji przedsiębiorczej, tj. przedsiębiorczych postaw (attitudes), wskazywanych jako jeden z najistotniejszych celów kształcenia młodych ludzi w dokumentach KE i dalej - materiałach edukacyjnych i podręcznikach - można zauważyć, że także i ono odpowiada sensualistycznej wizji człowieka. Pojęcie to ma swoje korzenie w naukach biologicznych; początkowo oznaczało uzewnętrznienie emocji i odnosiło się do zwierząt, a dalej - do fizjologii człowieka. Określenie to w XX w. zostało przyjęte na gruncie psychologii jako określenie „nastawienia umysłu” - jakoby umysł mógł przyjąć określoną „emocjonalną postawę”, niczym zwierzę reagujące na napastnika czy rywala (Dezinger, 1997: 136).

Przyjęcie takiego wyobrażenia na temat człowieka i jego natury dla wyjaśnienia sposobu jego poznawania, uczenia się i działania, prowadzi do licznych nieprawidłowości w jego kształceniu i wychowywaniu (Woźniak, 2018a), co dotyczy także edukacji przedsiębiorczej. Brak rzeczywistych efektów pracy nauczycieli, tworzenie systemów opartych na przymusie w instytucjach edukacyjnych i organizacjach gospodarczych, instrumentalne traktowanie człowieka jako przedmiot oddziaływania, a dalej destrukcyjne tego skutki społeczne i gospodarcze - to tylko niektóre z wynikających z tego problemów.

\section{Człowiek rozumny}

Rozwiązanie dla prezentowanych błędów w założeniach teoretycznych i wynikających $\mathrm{z}$ nich $\mathrm{w}$ praktyce problemów oferuje filozofia realistyczna. Odkrycia filozofów

\footnotetext{
${ }^{8}$ Korzeni takiej wizji można doszukać się w założeniu Platona na temat człowieka i jego dualistycznej, skonfliktowanej natury. Błąd ten został skorygowany przez Arystotelesa, jednak jego odkrycie zostało pominięte.

${ }^{9}$ http://www.podrecznik.edugate.pl/ EduGate 2014; Przedsiębiorczość w praktyce. Podręcznik dla szkół ponadgimnazjalnych do podstaw przedsiębiorczości i ekonomii w praktyce, Poznań 2014.
} 
realistycznych ${ }^{10}$, zwłaszcza dotyczące natury ludzkiej ${ }^{11}$, rozwiązują niedorzeczności wizji proponowanych przez inne tradycje filozoficzne (Krąpiec, 1996), z których wywodzi się większość koncepcji, metod i narzędzi opracowywanych na gruncie nauk społecznych i pedagogicznych.

Filozofowie realistyczni wykazali, że człowiek ma przede wszystkim naturę rozumną, a nie tylko sensualistyczną. To właśnie posiadanie przez człowieka intelektu (rozumu) i woli odróżnia go od innych istot żyjących (por. Arystoteles, Metafizyka). Intelekt oraz wola są władzami duchowymi człowieka; są to więc władze umysłowe, a nie zmysłowe.

Co więcej, wola człowieka nie ogranicza go do realizacji jego własnych „wielu potrzeb”, ale kieruje go do jego celu (Woźniak, 2018a za: Arystoteles, Tomasz z Akwinu), jakim jest dobro.

Określenie tego, czym to dobro jest, nie leży w gestii urzędników KE ani pracowników uniwersytetów, autorów podręczników i publikacji albo nauczycieli. Może ono być różnie rozumiane w zależności od unikalnej sytuacji i możliwości konkretnego człowieka (Krąpiec, 2015). Za pomocą ściśle współpracującego z wolą intelektu człowiek samodzielnie może dobro rozpoznać, chcieć je lepiej poznawać i do niego dążyć (Woźniak, 2018a). Przy tym zmysły, niezbędne do dostarczania treści poznawczych dla intelektu, mogą także wspierać poznawanie i dążenie, podejmowanie kierujących do uzyskania celu działań. Emocje, uczucia, jeśli są poddane władzy rozumu, także mogą służyć człowiekowi w jego dążeniu do dobra (Tomasz z Akwinu, ST, t.9,10).

$\mathrm{Z}$ tej perspektywy jedynie rzeczywiście dobrowolne poznanie dobra przez konkretnego człowieka, kierującego się własną wolą i rozumem może pobudzić jego wolę, wzbudzić chęć podejmowania działań. W ten sposób, dzięki własnemu rozumnemu pragnieniu woli - człowiek wybiera swój cel.

\section{Znaczenie celu}

Cel, jaki stawia przed sobą człowiek, jest w związku z tym nadrzędny wobec wiedzy w postaci przyswajanych treści - oraz podejmowanych działań - i to właśnie ów cel je porządkuje i organizuje (Woźniak, 2018a za: Arystoteles, Metafizyka, Tomasz z Akwinu, SCG). Z tej perspektywy założenie o konieczności zewnętrznego przymusu; tj. oddziaływania na chęci - wolę, intencje, motywację - w nauczaniu jest założeniem nierealnym, a oparte na takim założeniu działania nie mogą przynieść zamierzonego rezultatu (Woźniak, 2018a).

Wprawdzie w dokumentach KE (2019) oraz niektórych podręcznikach jest mowa o samodzielnym stawianiu i wyborze celów przez przedsiębiorców (np. Makieła, Rachwał, 2015), jednak równocześnie w treściach kształcenia podawane są zdefiniowane cele prowadzenia działalności gospodarczej i dalej - prowadzące do ich realizacji środki.

\footnotetext{
${ }^{10}$ Arystoteles, Tomasz z Akwinu, J. Gilson, a w Polsce: M.A. Krąpiec, M. Gogacz, J. Woroniecki.

${ }^{11} \mathrm{Z}$ perspektywy realistycznej natura człowieka nie jest dualistyczna, czyli człowiek nie jest „podzielony”, ale jest jednością, co ma zasadnicze znaczenie dla postrzegania człowieka, jego decyzji, działań i rozwoju (zob. Golonka, 2018). Wyraża się to m.in. w niemożliwości rzeczywistego oddzielenia różnych sfer funkcjonowania konkretnego człowieka - sfery ekonomicznej, społecznej i moralnej. Takie podziały człowiek może tworzyć jedynie w umyśle (por. Krąpiec, 1996). Wprawdzie „ojciec ekonomii” Adam Smith brał jeszcze pod uwagę tę jedność człowieka, wyrażającą się chociażby w niemożliwości oddzielenia jego decyzji ekonomicznych od kwestii społecznych i moralnych (zob. McCloskey, 2008, Huhn, 2018), jednak kolejni teoretycy nauk społecznych, a także pedagogicznych, jej nie uwzględnili.
} 
Prezentowanie uczniom czy studentom celów, takich jak zysk ekonomiczny, korzyści osobiste, efektywność, prowadzić może do ograniczenia, a nawet - wykluczenia możliwości poznania i osiągniecia przez ucznia jego dobra rzeczywistego. Koncentracja na tak zdefiniowanych celach eliminuje poza tym samą istotę działalności przedsiębiorczej, mogącej służyć rozwojowi i upodmiotowieniu osoby ludzkiej (zob. Woźniak, 2018). Wiedzie to w logicznej konsekwencji zamiast tego do uprzedmiotowienia i degradacji natury ludzkiej - dehumanizacji (por. Craze, 2018).

Im wyższy człowiek stawia sobie cel, tym lepsze jest jego poznanie i większe możliwości rozwoju. Co więcej, cel może transcendować człowieka - kierować go ponad zaspokajanie własnych potrzeb i korzyści. W przypadku każdej osoby może to oznaczać coś nieco innego, zważywszy na to, że każda osoba jest inna i ma unikalne możliwości i warunki (Krapiec, 2015).

W praktyce społeczno-gospodarczej można obserwować przykłady osób, które w taki sposób, posługując się własnym rozumem i wolą, są zdolne do rezygnacji z własnych korzyści, wybierając większe dobro - np. przedsiębiorca rezygnujący z możliwości sprzedaży swojego przedsiębiorstwa i wzbogacenia się, aby nadal dostarczać swoim klientom produkty wysokiej jakości, człowiek rezygnujący z intratnej pracy w instytucji i rozpoczynający własną działalność, żeby dawać przykład przedsiębiorczości własnym dzieciom, czy pracownik, który pomimo utraty korzyści materialnych odchodzi z przedsiębiorstwa realizującego wątpliwy moralnie cel (por. Golonka, 2020, w publikacji).

\section{Dobro wspólne}

Dobro większe od osobistych korzyści w tradycji realistycznej określane jest jako dobro wspólne. Dobro wspólne rozumiane jest tutaj przede wszystkim z naciskiem na dobro, a nie tylko wspólne, gdyż inaczej prowadzi do podporządkowania osoby ludzkiej kolektywowi (Krąpiec, 2015), jak to ma miejsce w licznych współczesnych organizacjach (zob. Golonka, 2018, 2020 w publikacji).

Pojęcia dobra i dobra wspólnego w edukacji - w tym przedsiębiorczej - zostały praktycznie pominięte. W większości podręczników i publikacji dostępnych dla uczniów i studentów społeczny kontekst działalności przedsiębiorczej sprowadza się do wzmianek o konieczności działania zgodnie z „wartościami etycznymi”. Wprawdzie w niektórych publikacjach jest mowa o „dobrym przedsiębiorcy” (m.in. Rachwał, 2012: 6), jednak rozumiane jest to głównie w kontekście jego cech czy umiejętności oraz przestrzegania owych wartości. Fakt, że człowiek, mając naturę rozumną, zdolny jest do samodzielnego poznawania i wybierania dobra, nie jest uwzględniony. Zresztą, poznawanie i wybieranie dobra nie wynika z przestrzegania jakiegoś kodeksu etyki, ale raczej z wierności rzeczywistości, tj. poznawanej prawdzie - która jest dobrem ludzkiego intelektu (Woźniak, 2018b za: Arystoteles, Tomasz z Akwinu, DV).

Perspektywa realistyczna ukazuje, że dobry przedsiębiorca to taki, który realizuje cel zgodny z naturalnym rozwojem rozumnej natury człowieka. Konsekwentnie, dobrym przedsiębiorstwem jest taka organizacja, w której ludzie rzeczywiście dobrowolnie tworzą, poprzez własną pracę, rzeczywiste dobra dla innych ludzi - klientów - w postaci usług czy produktów i dzięki temu sami stają się lepsi (zob. np. O’Brien, 2009; Sison i in., 2011). Już samo wytwarzanie i dostarczanie innym rzeczywistych dóbr może stanowić dobro wspólne przedsiębiorstwa i pracujących w nim ludzi - oraz służyć ich rozwojowi (Sison i in., 2011, Tomasz z Akwinu, DV). 
Ponieważ to cel porządkuje, czyli organizuje działania rozumiejących i dobrowolnie wybierających go ludzi, dotyczy to nie tylko indywidualnych przedsiębiorców, ale i współpracujących w ramach przedsiębiorstwa osób. Rozumne pragnienie osiągnięcia tego samego celu przez każdą z osób wyklucza stosowanie wszelkich form zewnętrznego przymusu w postaci systemów „zachęcania”, „motywowania”, czyli prób oddziaływania na ich wolę.

Nie zakłada to braku możliwości czy rezygnacji z zarabiania albo osiągania zysku, ale jest to nie celem działalności przedsiębiorczej, a raczej efektem osiągania zgodnego z rozumną naturą człowieka celu. Jego realizacja zapewnia człowiekowi rozwój i prawdziwe szczęście (por. Golonka, 2020, w publikacji, za: Tomasz z Akwinu, DV, ST).

\section{Rola nauczyciela}

Z perspektywy realistycznej rola nauczycieli w edukacji jest drugorzędna (Woźniak, 2018a). Uczeń sam jest w stanie rozpoznać i chcieć realizować dobro. Natomiast znacznie istotniejsze $\mathrm{z}$ tej perspektywy znaczenie ma ideał wychowawczy (Woźniak, 2018a), który może poruszyć wolę człowieka (Majkrzak, 2012) i zachęcić uczniów do urzeczywistniania go we własnym życiu.

Takim ideałem wychowawczym może być osoba nauczyciela, lecz tylko wówczas, gdy on sam przez swoją postawę, własne wybory dobra - większego niż osobiste korzyści i podejmowanie służących jego realizacji działań staje się dla uczniów przykładem, który oni mogą chcieć naśladować (Woźniak, 2018a).

W praktyce, w obecnie obowiązujących rozwiązaniach organizacyjnych i formalnych w instytucjach edukacyjnych, dokonywanie takich wyborów wydaje się mało realne. Jak wykazała wcześniejsza analiza, systemy przymusu zbudowane na podstawie sensualistycznej wizji człowieka obejmują także nauczycieli i kształcących ich pracowników szkół wyższych. Sami, będąc zmuszani do realizacji predefiniowanych celów (efektywnościowych, finansowych i innych, wyznaczanych przez urzędników UE, instytucje akredytacyjne itp., zob. więcej: Golonka, 2018), mają ograniczone możliwości urzeczywistnienia ideału wychowawczego i dawania przykładu swoim uczniom.

W efekcie, w instytucjach mających służyć przede wszystkim rozwojowi intelektualnemu człowieka - zwłaszcza w szkołach, uczelniach, instytucjach badawczych - pracownicy pracują nad realizacją innych celów, często stojących w sprzeczności z naturalnym rozwojem rozumnej natury ludzkiej. Stawiane cele i idące za nimi rozwiązania formalne i organizacyjne, w tym różne formy motywowania i kontroli, zmuszają pracowników intelektualnych do odejścia od realizacji rzeczywistego dobra, którym dla ludzkiego intelektu jest prawda.

Sytuację tę podsumowali m.in. H. Aguinis i in. (2014), G.F. Davis (2015), B.A. Nosek., J.R. Spies, M. Motyl (2012), zwracając uwagę na fakt, że w środowisku akademickim nie ma już znaczenia, co jest prawdziwe, ani co przyczyni się do rzeczywistego rozwoju wiedzy, ale to, co służy rozwojowi indywidualnych karier. Konsekwencją tego jest koncentracja na realizacji własnej kariery przez wiekszość współczesnych pracowników akademickich (Golonka, 2018 za: Ware, 2015). Podobnie rzecz się ma w szkołach i instytucjach edukacyjnych, gdyż to przez nauczycieli akademickich kształceni są nauczyciele niższego szczebla edukacji. 
Jak wynika z dostępnych badań (np. zob. w Wielkiej Brytanii - G. Kinman i S. Wray, 2013), nie służy to nawet im samym; pracownicy szeroko rozumianego sektora edukacji cierpią obecnie znacznie częściej niż pracownicy innych sektorów na różnego rodzaju zaburzenia i choroby umysłowe. Są one nie tylko wynikiem coraz większej presji na realizację stawianych przed nimi celów i zwiększania efektywności pracy (Kinman, Wray, 2013), ale także, a może przede wszystkim - skutkiem kompromisów intelektualnych, prowadzących do „dobrowolnie przymusowej” rezygnacji z poszukiwania i poznawania prawdy, czyli porzucenia rzeczywistego dobra, i coraz większego odrealnienia - oddalenia od rzeczywistości - w zamian za utrzymanie zatrudnienia i realizację osobistej kariery (por. Golonka, 2018).

Trudno w takiej sytuacji o możliwość urzeczywistnienia w instytucjach edukacyjnych ideału wychowawczego, zdolnego poruszyć wolę uczniów czy studentów, zachęcić ich do wyboru większego dobra, stawiania sobie wyższych celów, podejmowania przedsiębiorczych działań umożliwiających rozwój własnej osoby i szerzej - prowadzących do rzeczywistego rozwoju społeczno-gospodarczego.

Tworzenie warunków dla takiego rozwoju wymaga przede wszystkim weryfikacji obecnych rozwiązań organizacyjnych i formalnych, zwłaszcza w instytucjach mających służyć rozwojowi intelektualnemu człowieka - w szkołach, uczelniach, uniwersytetach, instytucjach naukowych i naukowo-badawczych - przy uwzględnieniu dorobku realistycznej tradycji intelektualnej, umożliwiającej powrót do rzeczywistości, i w oparciu o nią, konstruktywne zmiany na lepsze.

\section{Podsumowanie}

W pracy zaprezentowane zostały cel, który KE postawiła przed krajami członkowskimi, oraz środki mające do niego prowadzić. Jednym z najistotniejszych z nich, zdaniem urzędników, jest edukacja przedsiębiorcza. Jednak efekty działań edukacyjnych, jak też i wspierających rozpoczynanie oraz prowadzenie działalności przedsiębiorczej - takie jak różnego rodzaju wsparcie instytucjonalne i finansowe - niekoniecznie przekładają się na rzeczywistość społeczno-gospodarczą. W szerszym kontekście obserwowane są natomiast liczne negatywne skutki edukacji menedżerskiej i biznesowej. Także i związek postawionego celu z rzeczywistym rozwojem społeczno-gospodarczym może budzić wątpliwości. Poszukując przyczyn tych problemów, zarówno jeśli chodzi o brak efektów działań nauczycieli, jak i nadużycia, do których dochodzi w praktyce, dokonana została analiza wiedzy przekazywanej uczniom i studentom przedsiębiorczości, czyli treści kształcenia, a dalej także sposobu nauczania. U ich podstaw leży przyjęta przez filozofów nowożytnych niepełna, a przez to błędna koncepcja człowieka i jego natury. Opracowywane na podstawie niej teorie, metody i narzędzia wykorzystywane $\mathrm{w}$ edukacji, jak też i w praktyce gospodarczej, zakładają możliwość, a nawet konieczność traktowania człowieka jako obiektu zewnętrznego oddziaływania i kontroli. Prowadzi to do uprzedmiotowienia człowieka i licznych nadużyć względem niego - zarówno w edukacji, jak i praktyce społeczno-gospodarczej. W efekcie nie służy to uczniom i studentom, menedżerom oraz pracownikom przedsiębiorstw ani samym nauczycielom i wykładowcom. Remedium na te problemy można odnaleźć u filozofów realistycznych, oferujących pełne wyjaśnienie natury ludzkiej. Podkreślają oni znaczenie samodzielności człowieka, kierującego się własnym rozumem i wolą, oraz jego zdolność do poznawania i wyboru dobra. Perspektywa 
realistyczna uwzględnia także znaczenie samodzielnie wybranego celu, który w stosunku do przyswajanej wiedzy i podejmowanych przez człowieka działań jest nadrzędny, tzn. porządkuje je - organizuje. Odnosi się to zarówno do działalności przedsiębiorczej indywidualnych osób, jak i do działań podejmowanych we współpracy z innymi. Z perspektywy realistycznej rozwój społeczno-gospodarczy rozpatrywany jest w kontekście dobra wspólnego. Realizacja tego dobra jest efektem wyborów poszczególnych osób, stawiających sobie za cel dobro większe od osobistych korzyści. W przypadku każdej osoby dobro to może być rozumiane nieco inaczej, w zależności od indywidualnych możliwości i sytuacji. Realizacja rozwoju rozumnej natury człowieka, jak też i dobra wspólnego, możliwa jest jedynie w warunkach wolności jego poznawania oraz podejmowania działań służących jego realizacji. Dotyczy to zwłaszcza działalności edukacyjnej i przedsiębiorczej, która angażuje sferę duchową człowieka, tj. jego intelekt i wolę. W miejsce systemów przymusu realiści wskazują na znaczenie przykładu, czyli ideału wychowawczego, zdolnego do poruszenia woli człowieka i chęci urzeczywistnienia go w swoim życiu.

Realne zmiany mające na celu tworzenie warunków do rozwoju człowieka i społeczeństwa wymagają przede wszystkim weryfikacji obecnych rozwiązań organizacyjnych i formalnych, zwłaszcza w instytucjach edukacyjnych i naukowych, a dalej ich zmiany $\mathrm{z}$ uwzględnieniem dorobku realistycznej tradycji intelektualnej.

Literatura

References

Abela, A.V. (2001). Profit and more: Catholic Social Teaching and the purpose of the firm. Journal of Business Ethics, 31(2), 107-116.

Albornoz, C., Martinez, V. (2016). The effect of entrepreneurship education in college students: the mediating role of previous exposure to the family business (Research plan, School of Business and Economic Universidad del Desarrollo. Pozyskano z : https://negocios.udd.cl/files/2016/10/ Albornoz-Martinez-2016-.pdf

Alderfer, C.P. (1969). An Empirical Test of a New Theory of Human Needs. Organizational Behavior and Human Performance, 4, 142-175.

Aguinis, H., Shapiro, D.L., Antonacopoulou, E.P., Cummings T.G. (2014). Scholarly impact: A pluralist conceptualization. Academy of Management Learning and Education, 13, 623-639.

Arystoteles. (2019). Metafizyka. Warszawa: PWN.

Arystoteles. (1990). Organon. Warszawa: PWN.

Baker, T., Miner, A., Eesley, D. (2003). Improvising firms: bricolage, account giving, and improvisational competency in the founding process. Research Policy, 32, 255-276.

Bachrach, D.G. i in. (2017). On Academic Rankings, Unacceptable Methods, and the Social Obligations of Business Schools. Decision Sciences, 48(3).

Barnard, B., Herbst, D. (2018). Entrepreneurship, innovation and creativity: the creative process of entrepreneurs and innovators. Expert Journal of Business and Management, 7(1), 107-146.

Barroso-Tanoira, G., Barroso-Tanoira, F. (2017). Motivation for increasing creativity, innovation and entrepreneurship. An experience from the classroom to business firms. Journal of Innovation Management, 5, 55-74.

Begley, C.G. (2013). Reproducibility: Six red flags for suspect work. Nature, 497(2013), 433-434.

Benessia, A., Funtowicz, S., Giampietro, M., Pereira, A., Ravetz, J., Saltelli, A., Strand, R., Sluijs, J. (2016). The right place of science: Science on the verge. Consorcium for Science, Policy \& Oucomes, Arizona State University.

Bennis, W., O'Tole, J. (2005). How business schools lost their way. Harvard Business Review, 83(5), 96-194. 
Berkowitz, L. (1969). Social Motivation. In: G. Lintzey, E. Aronson, W. Addison, The Handbook of Social Psychology. USA, 50-135.

Bird, B. (1992). The Operation of Intentions in Time: The Emergence of the New Venture. Entrepreneurship Theory and Practice, 17, 11-20.

Buczyńska, T. (2007). Mikroekonomia. Warszawa - Łódź: Wydawnictwo Szkolne PWN.

Bućko, J., Wąsik, L.T., Filipowicz, J. (2005). Ekonomika przedsiębiorstwa. t. I. Radom: Politechnika Radomska.

Cardon, M., Joakim, W., Jagdip, S., Matea, D. (2009). The nature and experience of entrepreneurial passion. Academy of Management Review, 34, 511-532.

Cardoso, A., Cairrao, A., Petrova, D., Figueiredo, J. (2018). Assessment of the Effectiveness of the Entrepreneurship Classes in the Bulgarian Secondary Education. Journal of Entrepreneurship Education, 21(2), bns.

Chia, R., Holt, R. (2009). Strategy without design. The silent efficacy of indirect action. Cambridge: Cambridge University Press.

Chia, R., MacKay, B. (2007). Post-processual challenges for the emerging strategy-as-practice perspective: Discovering strategy in the logic of practice. Human Relations, 60(1), 217-242.

Craze, G. (2019). Corporate Social Responsibility and Dehumanization. Philosophy of Management, 18, 43-53.

Danziger, K. (1996). Naming the Mind. How Psychology Found Its Language. Oxford: Sage.

Davis, G.F. (2015). Editorial essay: what is organizational research for? Administrative Science Quarterly, 60(2), 179-188.

DeTienne, D.R., Chandler, G.N. (2004). Opportunity identifi cation and its role in the entrepreneurial classroom: A pedagogical approach and empirical test. Academy of Management Learning and Education, 3(3), 242-257.

Dogan, E. (2015). The Effects of Entrepreneurship Education on Entrepreneurial Intentions of University Students in Turkey. Ekonometri ve İstatistik Sayl, 23, 79-93.

Dodatkowe dokumenty KE. Pozyskano z: https://ec.europa.eu/growth/smes/promoting-entrepreneurship/support/education_en

Donaldson, L. (2002). Damned by our own theories: Contradictions between theories and management education. AOM Learning and Education, 1(1), 96-106.

Donham, W.B. (1933). The Failure of Business Leadership and the Responsibility of the Universities. Harvard Business Review, 11(4), 418-436.

Drucker, P. (1955). The practice of management. Oxford: Butterworth Heinemann.

Duska, R.E. (1997). The why's of business revisited. Journal of Business Ethics, 16(12/13), 1401-1409.

EduGate. (2014). Przedsiębiorczość w praktyce. Pozyskano z: https://zasobyip2.ore.edu.pl/uploads/ publications/44e33f66b612afab5cfe9bbd9acaad54_/wstep/index.html

European Commission. (2012). Effects and impact of entrepreneurship programmes in higher education. Report prepared in 2012 for the European Commission - DG Enterprise and Industry by EIM Business \& Policy Research (the Netherlands). The core project team consisted of Petra Gibcus, Dr. Jan de Kok, Jacqueline Snijders, Lia Smit and Bram van der Linden.

European Commission/EACEA/Eurydice. (2016). Entrepreneurship Education at School in Europe. Eurydice Report. Luxembourg: Publications Office of the European Union.

Fama, E.F. (1980). Agency problems and the theory of the firm. Journal of Political Economy, 88(2), 288-307.

Favolle, A., Gailly, B. (2013 - published 2015). The Impact of Entrepreneurship Education on Entrepreneurial Attitudes and Intention: Hysteresis and Persistence. Journal of Small Business Management, 53(1), 75-93.

Favolle, A., Gailly, B. (2015). The Impact of Entrepreneurship Education on Entrepreneurial Attitudes and Intention: Hysteresis and Persistence. Journal of Small Business Management, 53(1), bns.

Ferreira, J.J., Raposo, M.J., Rodrigues, R.G., Dinis, A., do Paço, A. (2012). A model of entrepreneurial intention: An application of the psychological and behavioral approaches. Journal of Small Business and Enterprise Development, 19(3), 424-440. 
Fontrodona, J., Sison, A.J. (2006). The nature of the firm, agency theory and shareholder theory: A critique from philosophical anthropology. Journal of Business Ethics, 66(1/II), 33-42.

Freeman, R.E., Wicks, A.C., Parmar, B. (2004). Stakeholder theory and "The corporate objective revisited". Organization Science, 15(3), 364-369.

Friedman, M. (1970). The social responsibility of business is to increase its profits. The New York Times Magazine, 13 September.

Ghoshal, S. (2005). Bad Management Theories Are Destroying Good Management Practice. Academy of Management Learning and Education, 4(1), 75-91.

Golonka, M.. (2020). Alicja i organizacje z krainy Szalonego Kapelusznika [w publikacji].

Golonka, M. (2018). Komu potrzebni są naukowcy?. Kraków: Wydawnictwo Impuls.

Grichnik, D., Smeja, A., Welpe, I. (2010). The importance of being emotional: How do emotions affect entrepreneurial opportunity evaluation and exploitation? Journal of Economic Behavior \& Organization, 76(1), 15-29.

GUS. (2017). Zmiany strukturalne grup podmiotów gospodarki narodowej w rejestrze REGON, $2016 r$. Pozyskano z: https://stat.gov.pl/obszary-tematyczne/podmioty-gospodarcze-wyniki-finansowe/ zmiany-strukturalne-grup-podmiotow/zmiany-strukturalne-grup-podmiotow-gospodarki-narodowej-w-rejestrze-regon-2016-r- $1,19 . \mathrm{html}$

Handy, C. (2002). What's a business for?. Harvard Business Review, 80(12), 49-55.

Hawaj, W. (2019, 12 czerwca). W: K. Puchalska, A. Kasprzyk, P. Pusz (red.). Podstawy przedsiębiorczości. Materiały dydaktyczne dla uczniów szkół ponadgimnazjalnych. Być przedsiębiorczym - nauka przez praktyke, s.5-16 Pozyskano z: http://wsp-inow.pl/?jet_download $=7268$

HEC. Paris, kursy kreatywności. Pozyskano z: https://www.classcentral.com/course/coursera-boosting-creativity-for-innovation-13125

Hmieleski, K.M., Corbett, A.C. (2003). Improvisation as a Framework for Investigating Entrepreneurial Action. In: D.H. Nagao (ed.), Academy of Management Best Paper Proceedings. NY: Briarcliff Manor, F1-F6.

Hoffman, A.J., Maynard, A. (2015; 12 stycznia 2018). American universities: reclaiming our role in socjety. The Conversation. Academic rigour, journalistic flair. Pozyskano $\mathrm{z}: \mathrm{http}: / /$ theconversation. $\mathrm{com} /$ american-universities-reclaiming-our-role-in-society- 42522

Holcombe, R.G. (2006). Does the invisible hand hold or lead? Market adjustment in an entrepreneurial economy. Review of Austrian Economics, 19(2/3), 189-205.

Holmgren, C., From, J. (2005). Taylorism of the Mind: Entrepreneurship Education from a Perspective of Educational Research. European Educational Research Journal, 4(4), 382-390.

Huhn, M. (2017). Responsible Innovation: a Smithian Perspective. Philosophy of Management, 17, 41-57.

Hunt, J.G., Hill, J.W. (1969). The New Look in Motivational Theory for Organizational Research. Human Organization, 28, 100-109.

Jensen, M., Meckling, W. (1976). Theory of the firm: managerial behavior, agency costs and ownership structure. Journal of Financial Economics, 3, 305-360.

Jodgand, Y., Sharma, S. (2019). Entrepreneurship of Emotions is Critical for Future Leadership. Journal of Leadership Studies, 13(1), 87-89.

KE. (2019, 12 czerwca). The Entrepreneurship 2020 Action Plan. Pozyskano z: https://ec.europa.eu/ growth/smes/promoting-entrepreneurship/action-plan_pl

Kennedy, A.A. (2000). The end of shareholder value: Corporations at the crossroads. Cambridge, MA: Perseus.

Kinman, G., Wray, S. (2014). Taking its toll: rising stress levels in further education. University and College Union Stress Survey 2014. Pozyskane z: https://www.ucu.org.uk/media/7264/UCU-stresssurvey-2014/pdf/ucu_festressreport14.pdf

Koslowski, P. (2000). The limits of shareholder value. Journal of Business Ethics, 27(1/2), 137-148.

Kożuch, A., Dyhdalewicz, A. (2004). Ekonomika i organizacja przedsiębiorstwa. Białystok: Wyższa Szkoła Ekonomiczna.

Krąpiec, M.A. (2015). Język i świat realny. Lublin: Polskie Towarzystwo Tomasza z Akwinu.

Krąpiec, M.A. (2009). Człowiek jako osoba. Lublin: Polskie Towarzystwo Tomasza z Akwinu. 
Krąpiec, M.A. (1996). Psychologia racjonalna. Lublin: Wydawnictwo KUL.

Kużdżał, A. (2019, 12 czerwca). W: K. Puchalska, A. Kasprzyk, P. Pusz (red.), Podstawy przedsiębiorczości. Materialy dydaktyczne dla uczniów szkót ponadgimnazjalnych. Być przedsiębiorczym - nauka przez praktyke, 29-43. Pozyskano z: http://wsp-inow.pl/?jet_download = 7268

Latusek, D., Olejniczak, T., Piotrowski, W. (red.). (2018). Teoria organizacji. Nauka dla praktyki. Warszawa: Poltext.

Lichtarski, J. (red.). (2005). Podstawy nauki o przedsiębiorstwie. Wrocław: Wydawnictwo Akademii Ekonomicznej we Wrocławiu.

Lombard, G.F.F. (1971). Relativism in organizations. Harvard Business Review. 49(2), 55-65.

Majkrzak, H. (2012). Filozofia wychowania w ujęciu św. Tomasza z Akwinu. Człowiek w Kulturze, 17, 201-212.

Makieła, Z., Rachwał, T. (2012/2015). Krok w przedsiębiorczość. Podręcznik do podstaw przedsiębiorczości dla szkół ponadgimnazjalnych. Warszawa: Nowa Era.

Mayo, E. (1933). The Human Problems of an Industrial Civilization. UK: Routledge.

McCloskey, D. (2008). Adam Smith, the last of the former virtue ethicists. History of Political Economy, 40(1), 43-71.

Mendel, Z. (2012). Własna firma w praktyce. Warszawa: Difin.

Mikołajczyk, B., Krawczyk, M. (2006). Sektor przedsiębiorstw mikro, małych i średnich w krajach UE. Studia Europejskie, 2, 68-85.

Moreau, R., Raveleau, B. (2006). Les Trajectoires De L'intention Entrepreneuhriale. Revue Internationale PME, 19(2), 101-131.

Niedzielski, P. (2018). Stan rozwoju sektora MSP. Pozyskane z: http://2018.konferencja-sooipp.pl/files/ Rozwoj_MSP.pptx

Niesłuchowski, M. (2017; 2019, 17 czerwca). Krok w przedsiębiorczość (seria). Program nauczania podstaw przedsiębiorczości w zakresie podstawowym dla szkół ponadgimnazjalnych - Krok w przedsiębiorczość. Pozyskane z: https://www.nowaera.pl/oferta-edukacyjna/przed-reforma-2017/ szkoly-ponadgimnazjalne/podstawy-przedsiebiorczosci

Nosek, B.A., Spies, J.R., Motyl, M. (2012). Scientific utopia: II. Restructuring incentives and practices to promote truth over publishability. Perspectives on Psychological Science, 7, 615-631.

Overstreet, H.A. (1925). Influencing Human Behavior. New York: Norton.

O'Brien, T. (2009). Reconsidering the common good in a business context. Journal of Bussiness Ethics, $85,25-37$.

Perrin, F.A.C. (1923). The psychology of motivation. Psychological Review, 30, 176-191.

Pfeffer, J., Fong, C.T. (2002). The end of business schools? Less success than meets the eye. Academy of Management Learning \& Education, 1(1), 78-95.

PARP. (2006). Raport MSP. Pozyskano z: https://www.parp.gov.pl/storage/publications/pdf/2017 sektor\%20msp\%20w\%20polsce\%20i\%20ue.pdf

Pietraszewski, M., Strzelecka, K. (2015). Jak być przedsiębiorczym. Podręcznik podstaw przedsiębiorczości. Szkoła ponadgimnazjalna. Poznań: Empi2.

Podstawy przedsiębiorczości. Innowacyjny program „Być przedsiębiorczym”. Pozyskane z:

https://www.ur.edu.pl/file/91366/Innowacyjny\%20program\%20nauczania\%20z\%C2\%A0Podstaw\%20Przedsi\%C4\%99biorczo\%C5\%9Bci.pdf

Przedsiębiorstwa sektora MSP w Europie. Pozyskano z: https://ec.europa.eu/eurostat/statistics-explained/index.php/Statistics_on_small_and_medium-sized_enterprises

Puchalska, K., Kasprzyk, A., Pusz, P. (2018, 12 czerwca). Podstawy przedsiębiorczości. Materiaty dydaktyczne dla uczniów szkół ponadgimnazjalnych. UR. Materiały dydaktyczne dla uczniów szkół ponadgimnazjalnych wydane $\mathrm{w}$ ramach realizacji projektu „Być przedsiębiorczym - nauka przez praktykę" współfinansowane przez Unię Europejską w ramach Europejskiego Funduszu Społecznego. Pozyskano z: www.bp.ur.edu.pl 
Rachwał, T. (2012). Jestem przedsiębiorczy - kształtowanie postaw przedsiębiorczych wśród młodzieży z wykorzystaniem innowacyjnych metod i narzędzi. Projekt nr POKL.09.01.02-30-362/10. Pozyskano z: http://www.jestemprzedsiebiorczy.pl/att/Rachwal_O-projekcie.pdf

Rideout, E., Gray, D. (2013). Does Entrepreneurship Education Really Work? A Review and Methodological Critique of the Empirical Literature on the Effects of University-Based Entrepreneurship Education. Journal of Small Business Management, 51.

Robbins, E. (1943). Management-labor cooperation. Harvard Business Review, 21(4), 415.

Saltelli, A. (2016; 12 stycznia 2018). Science in crisis: from the sugar scam to Brexit, our faith in experts is fading. The Conversation. Pozyskano z: http://theconversation.com/science-in-crisis-from-thesugar-scam-to-brexit-our-faith-in-experts-is-fading-65016

Saltelli, A., Funowicz, S. (2017). What is science's crisis really about? Futures, 91, 5-11.

Sanchez, J.C. (2011). University training for entrepreneurial Competencies: Its impact on intention of venture creation. The International Entrepreneurship and Management Journal, 7(2), 239-254.

Sánchez-García, J.C., Hernández-Sánchez, B.R., Mayens A.W., (2019). Impact of Entrepreneurial Education Programs on Total Entrepreneurial Activity: The Case of Spain. Adm. Sci., 9, 25. doi:10.3390/admsci9010025

Sirelkhatim, F., Gangi, Y. (2015). Entrepreneurship education: A systematic literature review of curricula contents and teaching methods. Cogent Business \& Management, 2, 1-5.

Sison, A.J.G. (2007). Toward a common good theory of the firm: The Tasubinsa case. Journal of Business Ethics, 74(4), 471-480.

Sison, A.J., Ferrero, I. (2015). How different is neo-Aristotelian virtue from positive organizational virtuousness? Business Ethics: A European Review, 242.

Sison, I., Fontrodona, J.I. (2011). The Common Good of Business: Addressing a Challenge Posed by "Caritas in Veritate". Journal of Bussines Ethics, 100, 99-107.

Sison, A.J., Fontrodona, J.I. (2013). Participating in the Common Good of the Firm.

Smith, A. (1790/1976). In The theory of moral sentiments, the Glasgow edition of the works and correspondence of Adam Smith, vol. 1. Glasgow: Glasgow Publishers.

Smith, A. (1776/1976). An enquiry into the nature and causes of the wealth of nations, Glasgow edition of the works and correspondence of Adam Smith, vol. 2. Glasgow: Glasgow Publishers.

Stroen, L.A. (2014). Entrepreneurship in higher education: Impacts on graduates' entrepreneurial intentions, activity and learning outcome. Education + Training, 56(8/9), 795-813.

Strong, E.K. Jr. (1925). The Psychology of Selling and Advertising. New York: McGraw-Hill.

Sudoł, S. (2006). Przedsiębiorstwo - podstawowe nauki o przedsiębiorstwie. Warszawa: Polskie Wydawnictwo Ekonomiczne.

Tomasz z Akwinu (2007). Summa Filozoficzna (Summa Contra Gentiles). Poznań: W Drodze.

Tomasz z Akwinu (2001). De veritate. O prawdzie. Lublin: Wydawnictwo KUL.

Tomasz z Akwinu (1485; 2018, 9 września). Summa Teologiczna. Pozyskano z: http://katedra.uksw.edu. $\mathrm{pl} /$ katedra.htm

Troland, L.T. (1928). The Fundamentals of Human Motivation. New York: Van Nostrand. (Reprinted Hafner, New York, 1967.)

Watson-Pitt, D., Quigley, E. (2019). Business School Rankings for the 21st Century. Pozyskano z: https:// www.abis-global.org/news/business-school-rankings-for-the-21st-century

Ware, M. (2015). STM Report. An overwiev of Scientific and scholarly journal publishing.

International Association of Scientific, Technical and Medical Publishers Fourth Edition, The Netherlands. Pozyskano z: https://www.stm-assoc.org/2015_02_20_STM_

Report_2015.pdf

Wawrzyniak, B. (1998). Przedsiębiorczość - legitymacja do przyszłości. Przegląd Organizacji, 7.

Werner-Maliszewska, A., Zawadzka, A. (2015). Rola regulacji emocji i emocji pozytywnych w efektywnym funkcjonowaniu przedsiębiorców oraz firm. W: L.D. Czarkowska (red.), Business coaching jako dźwignia rozwoju przedsiębiorczości. Warszawa: Poltext, 55-64. 
Whyte, W. (1956). Human Relations Theory - a progress report. Harvard Business Review, 34(5), $125-132$.

Woźniak, A. (2018a). Znaczenie władz wolitywnych w teorii i praktyce nauczania domowego. Edukacja Otwarta, 2, 67-88.

Woźniak, A. (2018b). Georg Simmel on Communal Lie, Purpose and Faithfulness to Reality. Science \& Peace, 9(1), 95-112.

Young, P.T. (1936). Motivation of Behavior: The Fundamental Determinants of Human and Animal Activity. New York: Wiley.

Zaleznik, A., Christensen C.R., Roethlisberger, F.J., (1960). The Motivation, Productivity and Satisfaction of Workers: A Prediction Study. Beyond Motivation. Harvard Business Review, 38(3), 123-125.

Zampetakis, L., Kafetsios, K., Lerakis, M., Moustakis, V. (2016). An Emotional Experience of Entrepreneurship: Self-Construal, Emotion Regulation, and Expressions to Anticipatory Emotions. Journal of Career Development. 44. doi: 10.1177/0894845316640898.

Żurek, J. (red.). (2007). Przedsiębiorstwo, zasady działania, funkcjonowanie, rozwój. Gdańsk.

Monika Golonka, dr. Autorka zajmuje się naukowo zagadnieniami organizacji, realizmu, autonomii i wolności w działalności intelektualnej. Wykłada na ALK w Warszawie i pracuje naukowo jako niezależny badacz.

Monika Golonka, PhD. Author's research interests revolve around ideas of organisation, realism, autonomy and freedom in creative and intellectual work. She teaches at Kozminski University and works as independent researcher.

ORCID: 0000-0001-8312-4540

\section{Adres/Address:}

Akademia Leona Koźmińskiego

ul. Jagiellońska 59

03-301 Warszawa, Polska

e-mail: monika.golonka@protonmail.com 